\title{
Peers as Teachers in Physical Education Hip Hop Classes in Finnish High School
}

\author{
Anna-Maria Nurmi ${ }^{1}$, Marja Kokkonen ${ }^{2}$ \\ ${ }^{1}$ Muurame High School Jyvaskyla Finland, Finland \\ ${ }^{2}$ University of Jyvaskyla, Department of Sport Sciences, P.O. Box 35, FI-40014 University of Jyvaskyla, Finland \\ Correspondence: Anna-Maria Nurmi, Muurame High School Jyvaskyla Finland, Finland
}

Received: February 2, 2015 Accepted: February 26, 2015 Online Published: March 18, 2015

doi:10.11114/jets.v3i3.659

URL: http://dx.doi.org/10.11114/jets.v3i3.659

\begin{abstract}
In this case study, theoretically rooted in peer-assisted learning (PAL), ten female high school students, acting as peer teachers, taught hip hop dance in a voluntary physical education course. The data, derived from questionnaires and interviews with the peer teachers, were analysed using content analysis. The results showed that the peer teachers considered dance an important subject in the weekly curriculum. On the one hand, peer teachers enjoyed the freedom of making the class look like their own, the fast learning of their students, and the increased self-confidence acquired over the course. On the other hand, most of them were self-critical and felt ashamed when making mistakes. They also felt uncomfortable teaching same-aged or slightly older peers, and were surprised at the unwelcoming and rather arrogant attitude of their students. This article illustrates not only the difficulties that a peer-teaching experiment can encounter, but also the value of peer teaching in offering positive experiences and engaging students in school PE through urban youth culture.
\end{abstract}

Keywords: peer teaching, hip hop dance, PAL, school culture, dance education

\section{Introduction}

Peer-assisted learning (PAL) has long been recognized in theory and in empirical research as an educational experience, which benefits students as both teachers and learners (Weidner \& Popp, 2007). Peer-assisted learning strategies include teaching by tutoring, modeling and student assessment along with approaches that include cooperative learning strategies (Cohen, 1994). Many studies have demonstrated the effectiveness of PAL in a variety of educational settings (Falchikov \& Goldfinch, 2000; Forneris et al., 2010; Harding \& Haven, 2009; Heron, Welsch \& Goddard, 2003) and in athletic training (Henning, Weidner, Snyder \& Dudley, 2012; Holt, Kinchin \& Clarke, 2012; Weidner \& Popp, 2007), including physical education (PE) (Ayvazo \& Ward, 2009; Ensergueix \& Lafont, 2010; Iserbyt, Elen \& Behets, 2010; Johnson \& Ward, 2001; Wallhead \& O'Sullivan, 2007; Ward \& Lee, 2005), where PAL has been seen as a best pedagogical practice (Siedentop \& Tannehill, 2000). However, as shown by Ward and Lee (2005) in their meta-analysis of 28 PAL studies in PE, only three were qualitative and none of them focused on peer teaching. Therefore, the general aim of the present study was to provide new qualitative knowledge of the experiences of peer teachers incorporating hip hop dance into traditional PE in Finnish high school.

With respect to the various types of PAL strategies adopted in school contexts, peer tutoring (PT), which builds on active student response, opportunity to respond, feedback, and reinforcement (Heron, Villareal, Yao, Christianson, \& Heron, 2006), is the most widely used and researched form. In PT students are arranged in pairs and instructed to assist their partner to complete instructional tasks (Ward \& Lee, 2005). In unidirectional PT, there is typically an asymmetrical relationship between a more knowledgeable or skilled tutor and a less-knowledgeable or unskilled tutee (Miller, Topping \& Thurston, 2010). In reciprocal or bidirectional peer tutoring (RPT), two or more same-aged students, generally coming from the same class group (De Backer, Van Keer, \& Valcke, 2012), are grouped together as pairs. They both function equally as tutor and tutee, and thus benefit from what Wood, Mustian, and Lo $(2013,34)$ call "double doses of practice". In contrast, cross-age PT involves a younger student and an older, generally more experienced student, whose advanced instruction is expected to refine or improve the skills of the tutee (Barfield, Hannigan-Downs, \& Lieberman, 1998). Class-wide peer tutoring (CWPT) involves the whole class, broken down into pairs or small groups, in the reciprocal roles of tutor and tutee (Cervantes, Lieberman, Magnesio, \& Wood 2013; 
Johnson \&Ward, 2001). Regardless of the research methodology, PT has proved to be an effective instructional strategy in PE with benefits such as increased academic learning time, increased moderate-to-vigorous physical activity levels, enhanced motor performance, and improved health and nutrition behavior, social interactions and social skills development, motivation and self-efficacy (Cervantes et al., 2013; Jenkinson, Naughton, \& Benson, 2013).

Typically PAL in school PE has been combined with ball games, such as volleyball (Ayvazo \& Ward, 2009), rugby (Wallhead \& Sullivan, 2007) and soccer (Holt, Kinchin \& Clarke, 2012). In this study, however, PAL was united with hip hop dance. Hip hop dance is an essential part of the hip hop culture that emerged in the 1970s in New York, with its roots in breaking, waacking and rap dancing (Hazzard-Donald, 2004; Keyes, 2008). However, of these three forms of dance, break dance is the most well-known form of hip hop, owing to its competitive, pantomimic and acrobatic nature. Hip hop dance and the whole hip hop culture started out as a subculture owned by the young people in the streets (Banes, 2004). Today, while hip hop culture has become a part of popular culture, it continues to offer young people a site of their own where they can be creative and experience accomplishments that are not possible in the adult world. Although the sexual, competitive, and confrontational forms of expressions and lower levels of playfulness in current hip hop dance have been argued by Engel (2011) to have a negative impact on the more precocious movers and shyer adolescents, and despite of a high injury rate among hip hop dancers (Ojofeitimi, Bronner, \& Woo, 2012), the fact that hip hop dance requires rather little dance ability and, at least at the beginning, no special equipment, and has its focus on social interaction and freedom of individual expression, have generally been seen as advantageous (Beaulac, Olavarria, \& Kristjansson, 2010).

Although the use of popular culture can connect students more closely to the subject matter and help educators to engage students (Collins, 2012), and even if hip hop, in particular, has been seen as a useful pedagogical tool to engage youth (Pardue, 2007), only a handful of studies have reported on the incorporation of hip hop elements into traditional school PE. In these studies, the focus has primarily been on the enhanced well-being and physical activity resulting from participation in hip hop dancing, and on the subjective experiences of the students dancing hip hop. More specifically, Romero (2012) demonstrated that a school-based hip hop break dance physical activity program increased adolescent girls' vigorous physical activity and self-efficacy. Along the same lines, Sungwoon and Jingu (2007) found that students assigned to hip hop dancing as part of PE and stress management classes scored high in positive well-being and showed diminished fatigue and psychological distress immediately after dancing hip hop. Harris, Wilks, and Stewart (2012) found that a health promotion intervention, including structured school-based hip hop classes and a signature event, resulted in enjoyable, positive life experiences, increased cooperation and solidarity, positive self-expression, and a renewed interest and connectedness with the school community. Pike (2000) further reported that hip hop dance gave a sense of pride to middle school students. Furthermore, a community-based hip hop dance physical activity program was shown to benefit adolescents' psychological, social, and physical well-being (Beaulac, Kristjansson, \& Calhoun, 2011). In our previous study based on data derived from student questionnaires and diaries, we focused on high school students' experiences of hip hop, taught by their peers, in PE and found that they experienced hip hop differently, depending on whether or not they had participated in an earlier hip hop class together with their peer teachers (Nurmi, Hirvensalo, \& Klemola, 2013). To date, none of the previous PE studies has investigated the experiences of peer teachers teaching hip hop —or any other dance form - to their peers.

This study was influenced by the notions that qualitative PAL studies in the PE context are rare (Ward \& Lee, 2005) and that the duration of peer-tutor training and how it has been implemented have also either not been fully described (Ensergueix \& Lafont 2011) or have varied greatly (Jenkinson et al., 2013). In addition, PAL has rarely been examined in conjunction with any form of popular culture, despite the earlier suggestions by Lengnick-Hall (1996) and Schneider and Bowen (1995) that student roles in school should be conceptualized in ways that go beyond traditional views of them as mere recipients of education: students should be more active and their voices should be heard. This is in line with the more recent perspective of model-based practice (MBP), where alternative pedagogical approaches to the traditional teacher-led practices in teaching PE, such as peer teaching, are highly welcomed (for a recent review see Casey, 2014). With these previous limitations and recommendations in mind, the purpose of this study was to explore qualitatively the experiences of peer teachers in high school PE. Our specific study objectives were to investigate how peer teachers felt right after doing their teaching, and to analyse where they thought they had succeeded and what they would have done differently.

\section{Methods}

\subsection{Setting and Participants}

This study was a case study (Stake, 2000) comprising ten hip hop dance course students. The formal PE teacher, the first author of the present study, was an essential participant in the study. Hip hop dance as a form of physical activity was chosen because of the formal teacher's dance background ( 30 years). To encourage students to be active 
participants and active doers, and to take youth culture better into account in PE classes by drawing specifically on the spirit of hip hop dance, with its focus on social interaction (e.g., Beaulac et al., 2010), the formal teacher decided to use PAL as a teaching strategy.

The site of the study was a high school with 320 students in southwestern Finland. The study was implemented in two phases (Figure 1). In the first phase, a hip hop club was established at the school in the academic year 2004-

2005 in order to support the 22 participating students' growth in independence, participation and creativity (Nurmi \& Hirvensalo, 2007; see also Nurmi et al., 2013). The hip hop club, held on a weekly basis for the whole academic year, consisted of 32 hours of hip hop dance. It served as hip hop dance skill training for the future peer teachers in the second phase of the study. The second phase, which is the object of this report, was a PE course held in 20052006. In the course, 10 peer teachers (tutors), aged 15 to 18 , the participants of the present study, planned and carried out a hip hop class for 17 students (tutees) with the help of the formal PE teacher. All the students enrolled in the course were given an opportunity to try teaching for the first time. Nine of the peer teachers had participated in the hip hop club the previous year. The students were active participants who had the possibility to influence the teaching content of the club and that of the course in both phases of the study.

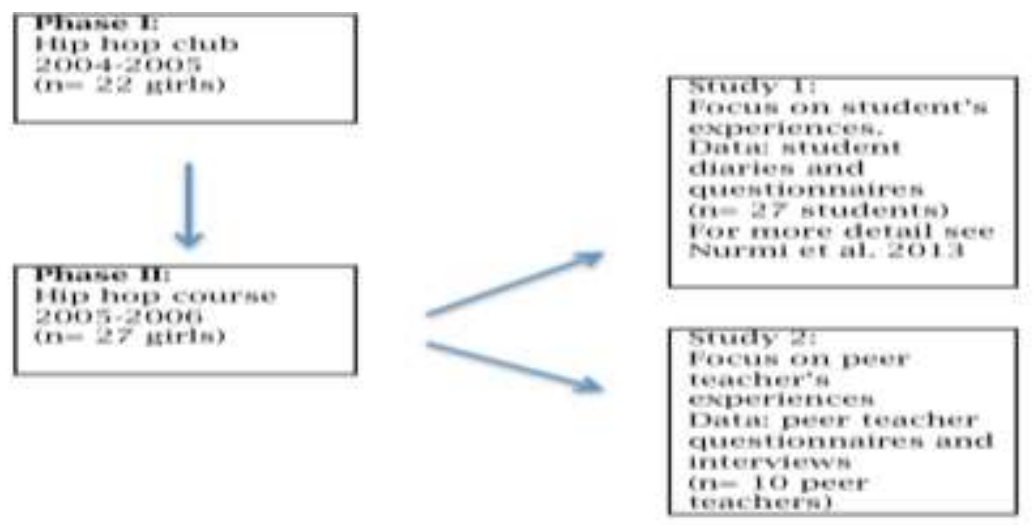

Figure 1. Research Phases

The elective PE course occupied 34 hours of which 18 hours focused on hip hop dance taught mainly by peer teachers, leaving 16 hours for other dance forms, such as ballet, show dance and contemporary dance, which were chosen by the students and taught by the formal PE teacher. Eight of the ten peer teachers taught hip hop dance in pairs with a teaching partner they had chosen themselves and two students (peer teachers numbers 4 and 6) alone, because their partners were sick on the teaching day. However, the two students who taught alone had planned the class with their partner. The peer teachers had been instructed to plan a hip hop dance class that had to include a warm-up, across-the-floor routines and choreography. The peer teachers created the movements and the routines to be taught, with as much help from the formal PE teacher as they wanted. Help included suggesting steps or movements, choosing the music or simply confidence-building support from the teacher. Some of the peer teachers requested more help and support with the planning of the class than others. The peer teachers were also encouraged to give feedback to their students.

During the course, the formal PE teacher taught the first three hip hop classes after which it was the peer teachers' turn to teach. The peer teachers taught a 60-minute class that started with a warm-up, continued with short dance routines done diagonally across the floor, and concluded with a specially developed dance routine. The peer teachers received face-to-face feedback from their formal PE teacher and written feedback from their peers after the class. The tutees received some prior instruction on their role as a student. Thus, the method of peer teaching used in this study most closely resembles that of the CWPT model. Here, the roles were more semi-reciprocal, since not every student acted as a peer teacher. The formal PE teacher highlighted the fact that everyone was teaching for the first time and hence the tutees should not be too judgmental.

\subsection{Data Collection and Analysis}

The data were collected by the first author in two forms. First, the peer teachers filled in a questionnaire concerning the planning of the class and the strengths and weaknesses of their own teaching. They were also invited to comment freely on anything in the class. Second, the peer teachers were individually interviewed by the formal teacher. The questions that guided the semi-structured interviews with the peer teachers were: What were your feelings after teaching? Where do you feel you succeeded? What would you have done differently? And is there anything you would like to comment on? Mean interview length was 35 minutes, ranging between 23 and 40 minutes. The interviews were audio-recorded 
and transcribed verbatim. The data totalled 52 pages (Times New Roman 12 point, paragraph 1, 5).

The data were analyzed using inductive content analysis (Mayring, 2000), in which the aspects of interpretation and the categories being developed are as close as possible to the data and formulated in terms of the data. In other words, the analysis contained no theoretically derived aspects (Mayring, 2000). According to Graneheim and Lundman (2004) and Mayring (2000), a basic issue when performing qualitative content analysis is to decide whether the analysis should focus on latent content, that is, what the text talks about, or manifest content, that is, what the text actually says. In this paper, the analysis focuses on the latent content dealing with the tutor-tutee relationship, and involves an interpretation of the underlying meaning of the text.

The main idea of inductive content analysis is to formulate a criterion of definition that is derived from the research question. This determines what aspects of the textual material are to be taken into account, such as what the unit of analysis will be. In this paper the unit of analysis was a whole sentence or a phrase that answered the question "How did the peer teachers experience teaching a hip hop class?" The unit of analysis helped to construct the coding rules for the data, thereby clarifying the categories. Following this criterion, as the data were worked through, tentative categories started to form and were deduced step by step. Through the feedback loop, these tentative categories were revised and eventually reduced to main- and sub-categories and checked for reliability. Four categories and nine sub-categories, shown in Table 1, were found in the data.

Table 1. Categories and Sub-Categories

\begin{tabular}{|c|c|c|c|c|}
\hline & A Planning a class & $\mathrm{B}$ Me as a teacher & $\mathrm{C} \mathrm{Me}$ as a teacher & $\begin{array}{l}\mathrm{D} \text { Dance in my weekly } \\
\text { curriculum }\end{array}$ \\
\hline \multirow[t]{3}{*}{ Sub-categories } & $\begin{array}{l}\text { A1)The framework for the } \\
\text { class }\end{array}$ & B1) Making mistakes & C1) Same aged friends & $\begin{array}{l}\text { D1) Dance is important in my } \\
\text { school curriculum }\end{array}$ \\
\hline & $\begin{array}{l}\text { A2) The content of the } \\
\text { class }\end{array}$ & B2) I would do it again & $\begin{array}{l}\text { C2)Students' arrogant } \\
\text { attitude }\end{array}$ & \\
\hline & & $\begin{array}{l}\text { B3) Feelings after my } \\
\text { teaching class }\end{array}$ & $\begin{array}{l}\text { C3) Students learned } \\
\text { fast }\end{array}$ & \\
\hline
\end{tabular}

Table 2. presents an example of the coding agenda with category definitions, prototypical text passages and rules for distinguishing different categories.

Table 2. Example of a coding agenda (Mayring 2000)

\begin{tabular}{|c|c|c|c|c|}
\hline CATEGORY & SUB-CATEGORY & DEFINITION & EXAMPLES & CODING RULES \\
\hline $\begin{array}{l}\text { B) } \mathrm{Me} \text { as a } \\
\text { teacher }\end{array}$ & $\begin{array}{c}\text { B1) } \\
\text { Making mistakes }\end{array}$ & $\begin{array}{l}\text { Peer teachers were } \\
\text { very self-critical }\end{array}$ & $\begin{array}{l}\text { "I'm a little disappointed with } \\
\text { myself and with my yelling and } \\
\text { forgetting things" ( } 4^{\text {th }} \text { hip hop } \\
\text { class, peer teacher \#4) } \\
\text { "I was really quiet and dull }\left(2^{\text {nd }}\right. \\
\text { hip hop class, peer teacher \#2.2) }\end{array}$ & $\begin{array}{l}\text { Peer teachers' self-criticism } \\
\text { pertaining to being a better } \\
\text { teacher and making things } \\
\text { better during their teaching }\end{array}$ \\
\hline $\begin{array}{l}\text { C) Students in } \\
\text { the class }\end{array}$ & $\begin{array}{l}\text { C2) Same aged } \\
\text { friends }\end{array}$ & $\begin{array}{l}\text { Same aged friends } \\
\text { were thought to be } \\
\text { difficult to teach }\end{array}$ & $\begin{array}{l}\text { "Teaching was hard because the } \\
\text { whole group was full of my } \\
\text { friends" ( } 1 \text { st hip hop class, peer } \\
\text { teacher "5.2) } \\
\text { "I would rather teach people } \\
\text { who are younger than me and } \\
\text { who don't have the same skills } \\
\text { as me" ( } 3^{\text {rd }} \text { hip hop class, peer } \\
\text { teacher \#3.1) }\end{array}$ & $\begin{array}{l}\text { All the thoughts that } \\
\text { mentioned a same-age peer } \\
\text { or a friend }\end{array}$ \\
\hline
\end{tabular}

\section{Results}

The first category formed was planning the class (A). Students felt that when planning their teaching with their peer, although the formal PE teacher gave them the framework, they had the freedom to make the class look more like theirs. "Well the timetable was given exactly, but everything else was kind of free. In other words, the framework was really clear. At first I felt scared but at the end it was great" ( $4^{\text {th }}$ hip hop class, peer teacher \#4).

The peer teachers felt that, despite being given the framework for the class, it was hard to plan the teaching content. Creating and inventing the steps and the movements was harder than the peer teachers had first thought. "It was hard to 
create combinations of steps and in the end we didn’t succeed in it so well!!” ( $3^{\text {rd }}$ hip hop class, peer teacher \#3.1). Finding the right kind of music and the right songs for the class was also hard for some of the peer teachers.

The second category of peer teacher's experiences was me as a teacher (B). The peer teachers were very critical of their own teaching and they wanted to do it successfully. "It felt that everything I did was incomplete. Especially the last combination, no one seemed to get that" ( $5^{\text {th }}$ hip hop class, peer teacher \#4). Making mistakes was something they all talked about and they reported feelings of shame that they were unable to avoid them in their teaching. "The teaching was kind of nice even though it felt stupid to make more mistakes than my students" ( $3^{\text {rd }}$ hip hop class, peer teacher \#3.1).

Despite their self-critical attitude almost all the peer teachers reported being willing to teach again. Many of them stated that they wanted to improve their teaching. "I would teach again, because I could then fix the mistakes I made this time" $\left(5^{\text {th }}\right.$ hip hop class, peer teacher \#5.1). The peer teachers' feelings after giving a class were mostly positive. "After getting my feedback [from the students] I got a lot more self-confidence" $\left(5^{\text {th }}\right.$ hip hop class, peer teacher \#5.2). The peer teachers also realized that occupying the role of a teacher was an exceptional situation, and a few of them were worried about how it might affect their reputation. "I hope that next year the freshmen will not think of me as above them or anything like that" $\left(2^{\text {nd }}\right.$ hip hop class, peer teacher \#2.1).

For the peer tutors, the age of the students in the class (C) was a critical factor in their teaching experience. The fact that the peer teachers were mostly the same age as their students was troublesome for almost every peer teacher. " $(\ldots)$ Teaching was hard because the whole group was full of my friends the same age" $\left(1^{\text {st }}\right.$ hip hop class, peer teacher \#1.1). The peer teachers felt that it was hard to give feedback to their peers. Some of the peer teachers also reported feeling uncomfortable when their students were slightly older than them. "It felt stupid forgetting things and all the more when some of the students were older than me" ( $5^{\text {th }}$ hip hop class, peer teacher \#5.2).

The peer teachers felt that the attitude of some of the students was arrogant. "The teaching experience was nice but I was so pissed off when I noticed that some of the students tried to tell us what to do" ( $3{ }^{\text {rd }}$ hip hop class, peer teacher \#3.1). The peer teachers felt that they could not achieve the teacher status in the eyes of their peers that they would have wanted. "The students' attitude surprised me... or I don't know if it's only in my head, but it felt that all the students were extremely negative towards us or at least they looked at us like what are they trying to (?)..." $\left(1^{\text {st }}\right.$ hip hop class, peer teacher \#1.2). The peer teachers also felt that their students were bored in their class and did not feel that their teaching the class was welcomed.

The most positive aspect of their classes in the peer teachers' view was that their students learned fast. The peer teachers were all very surprised at their student's skills, despite the heterogeneity in dancing skills in the group. "The students have learned surprisingly fast even though the course has only just started" ( $2^{\text {nd }}$ hip hop class, peer teacher \#2.1). The peer teachers believed that in their hip hop classes the students would learn new things and skills. "Students learned really easily, although we hadn't done the same things before" ( $3^{\text {rd }}$ hip hop class, peer teacher \#3.2).

Despite the peer teachers' rather negative experiences of teaching, they saw dance as an important part of their school curriculum (D). "(...) It was awesome to have this kind of course in my week schedule. Dancing is so much fun and the highlight of the week" ( $6^{\text {th }}$ hip hop class, peer teacher \#6). The whole school week started to feel easier for the peer teachers because they had something really inspiring to look forward to. Some of peer teachers wrote that their own hip hop culture started to form inside the school. Teaching in a PE course was also felt to be a great opportunity to try teaching for the first time and experience something different in school.

\section{Discussion}

The present qualitative study aimed at exploring the experiences of ten high school students who acted as peer teachers in voluntary hip hop classes in school PE. The results based on the interviews and questionnaires showed that the peer teachers considered dance an important subject in the weekly curriculum. On the one hand, the peer teachers enjoyed the freedom of making the class look like their own, the fast learning of their students, and the increased self-confidence they acquired over the course. On the other hand, most of them were self-critical and ashamed of the mistakes they made. They also felt uncomfortable teaching same-aged or slightly older peers, and were surprised by the unwelcoming and rather arrogant attitude of their students.

Hip hop dance inside the school culture was an important phenomenon for the students. They felt that for the first time in their school history the adult institution was acknowledging them. Planning the classes, mostly on their own, in pairs was a new experience for every peer teacher, and yet they succeeded in it. The peer teachers were pleased at being given the responsibility of teaching; while from the formal PE teacher's point of view this increased their dedication to their class. Planning the classes gave the peer teachers not only responsibility but also a voice inside the school, leading them to feel that they were an accepted part of the school culture. 
Our findings also revealed that peer teachers experienced teaching positively due to their freedom to plan the class and the fast learning of their students. In addition, many of the peer teachers were willing to try to teach again, which, in accordance with the findings of Galbraith and Winterbottom (2011), might reflect the enhanced self-confidence gained by the peer teachers over the PE course. This increased self-confidence might be a result of the tutor learning effect, as reported by Roscoe and Chi (2007).

On the other hand, most of the peer teachers were self-critical and felt ashamed of the mistakes they made while teaching. They experienced discomfort teaching same-aged or slightly older peers, and were surprised by what they felt to be an unwelcoming and rather arrogant attitude on the part of their students. Their expectations towards their own teaching seemed to be very high. Galbraith's and Winterbottom (2011) reported that adolescent biology tutors were concerned about their authority and knowledge of the subject, that is, not living up to the expectations of, or being taken seriously by, their younger tutees. In the present study, the peer teacher's self-criticism may have arisen from the fact that their students were same-aged peers, a typical situation in PAL interventions aimed at developing motor behaviours in PE (Jenkinson et al., 2013), and generally the rule in reciprocal peer tutoring (De Backer et al., 2012).

Peer teacher status is a construct based on power and status in the group (Lease, Kennedy, \& Axelrod, 2002). It is possible that teaching same-aged students felt hard because the teachers were unable to attain the teacher status they had expected. The failure to achieve teacher status may be connected with the students' age or it may be due to the fact that peer teaching is not very common in the Finnish school system. Although the Finnish National Curriculum (National Core Curriculum for Upper Secondary School 2003) expects and highlights the importance of an active student role and students' own decision making, the institution of school itself changes only slowly. In Finland the educational system is still very teacher- rather than student-centered when it comes to planning course contents. We believe that physical education is one of the subjects where student responsibility and an active role could easily be enhanced through peer teaching.

This study has a few limitations. First, the formal PE teacher, instead of allowing the students to select their teaching partners themselves, could have paired the students. Polvi and Telama (2000), in their study with 11-year-old girls, showed that working with the same person all the time does not promote social development. However, systematic assignments increased the likelihood of giving instructions and physical and psychological support, and of correcting errors. Second, the students in the present study could have been given another possibility to try teaching instead of just the one. Two or more teaching sessions would have normalised the teaching situation and the student would have acquired more routine in conducting it. Thirdly, some of the interviews were rather short, which makes a deeper understanding of peer teacher's experiences hard. Finally, as in all content analyses, we cannot be sure that we have interpreted the latent content of the text correctly. Methodologically, using member checking (Guba \& Lincoln, 1981), although seen as problematic and not always necessary in qualitative research (Carlson, 2010), would have reinforced our view that our interpretations actually represent the perspectives of the students.

Overall, the strengths of the study overcome the limitations. Following the recommendation of Houston-Wilson, Lieberman, Horton, and Kassler (1997) that piloting a peer-tutoring programme in PE should be done with a small group of students or a single class, we conducted this study in a single PE class with 27 female high school students. Unlike previous physical educational PAL studies that have provided few details of the duration and the description of the peer-tutor training (Ensergueix \& Lafont, 2011), and in which the length of peer-tutor training has varied from 20 minutes to 6 hours (Jenkinson et al., 2013), the peer-tutors in the present study were provided with a total of 32 hours of hip hop dance in the first phase of the study. In some earlier high school hip hop projects, students have not been fit and bodily aware enough to breakdance (Marsh, 2012); this was not an issue among the well-trained peer-teachers in our study. In order to ensure comprehensive data collection, the data were collected by means of both questionnaire and interview (method triangulation). A specific strength of this study is the dance experience of the first author, who at that time was the present participants' formal PE teacher.

Acknowledging the life of young people by means of hip hop dance could be one way of increasing student engagement in and out the school context. Student feelings of acceptance have been found to play a significant role in motivation, engagement in learning, and commitment to school (Osterman, 2000), and the several hip hop projects implemented in Canada have, in fact, been shown to help regulate high school students' attendance and enthusiasm for the curriculum, and to increase their rate of completion of education requirements and interest in post-secondary education (Marsh, 2012). On the question of engagement with PE, Lewis (2014) found that pupils who believed that they lacked skills in the traditional team sports and ball games typical of school PE had become alienated from PE, and lost their motivation to be physically active, partially due to the restricted range of activities included in school PE. We believe that hip hop dance could, at best, motivate students' engagement in school PE and also in greater physical activity outside of school. Physical activity in teenage is declining at a faster rate in Finland than in many other Western countries (Curie et al., 2008; Husu, Paronen, Suni, \& Vasankari, 2011), and new tools are needed to combat this health policy challenge. 
Our study also contributes to the ongoing discussion on activating students as peer teachers (e.g. Ayvazo \& Ward, 2009; Rohrbeck, Ginsburg-Block, Fantuzzo, \& Miller, 2003; Iserbyt et al., 2010; Ward \& Lee, 2005) and has practical implications for both school PE and PE teacher education. Hip hop is a suitable dance form for dance beginners, and hence can also be recommended for school PE and for peer teaching at school. Hip hop dance is an easy choice for both students and PE teachers due to its wide and simple movements, and also due to the fact that the music can easily be varied from a very slow tempo to a faster one. Therefore, we recommend that PE teacher education should seek to counter the vulnerability that PE teachers (e.g. Frazer-Thomas \& Beaudoin, 2002) and PE student teachers (e.g. Rustad, 2012) easily experience when faced with dance education by equipping them with sufficient dance skills, including hip hop, during their teacher education.

\section{References}

Ayvazo, S., \& Ward, P. (2009). Effects of Classwide Peer Tutoring on the Performance of Sixth Grade Students during a Volleyball Unit. Physical Educator, 66(1), 1-13.

Banes, S. (2004). "Breaking”. In M. Forman \& M. A. Neal (Eds.). That's the Joint. The Hip-Hop Studies Reader. New York: Routledge, 13-20.

Barfield, J. P., Hannigan, D, S., \& Lieberman, L. J. (1998). Implementing a Peer Tutor Program: Strategies for practitioners. Kinesiology, Sport Studies and Physical Education Faculty Publications. 69. http://digitalcommons.brockport.edu/pes_facpub/69

Beaulac, J., Kristjansson, E., \& Calhoun, M. (2011). 'Bigger than hip-hop?' Impact of a Community-Based Physical Activity Program on Youth Living in a Disadvantaged Neighborhood in Canada. Journal of Youth Studies, 14(8), 961-974. http://dx.doi.org/10.1080/13676261.2011.616488

Beaulac, J., Olavarria, M., \& Kristjansson, E. (2010). A Community-Based Hip-Hop Dance Program for Youth in a Disadvantaged Community in Ottawa: Implementation Findings. Health Promotion Practice, 11(1), 61-69. http://dx.doi.org/10.1177/1524839909353738

Casey, A. (2014). Models-Based Practice: Great White Hope or White Elephant? Physical Education and Sport Pedagogy, 19(1), 18-34. http://dx.doi.org/10.1080/17408989.2012.726977

Carlson, J. A. (2010). Avoiding Traps in Member Checking. The Qualitative Report, 15(5), 1102-1113.

Cervantes, C. M., Lieberman, L. J., Magnesio, B., \& Wood, J. (2013). Peer Tutoring: Meeting the Demands of Inclusion in Physical Education Today. Journal of Physical Education, Recreation \& Dance, 84(3), 43-48. http://dx.doi.org/10.1080/07303084.2013.767712

Cohen, E. G. (1994). Restructuring the Classroom: Conditions for Productive Small Groups. Review of Educational Research, 64(1), 1-35. http://dx.doi.org/10.3102/00346543064001001

Collins, K. (2012). Strategies for Using Pop Culture in Sport Psychology and Coaching Education. Journal of Physical Education, Recreation, and Dance, 83(8), 20-31. http://dx.doi.org/10.1080/07303084.2012.10598824

Currie, C., Gabhainn, S. N., Godeau, E., Roberts, C., Smith, R., Picket, W., \& Barnekow, V. (2008). Inequalities in young people's health. Health behaviour in school-aged children. International report from the 2005/2006 survey. (WHO Europe, Health Policy for Children and Adolescents No. 5). Retrieved from http://www.euro.who.int/_data/assets/pdf_file/0005/53852/E91416.pdf

De Backer, L., Van Keer, H., \& Valcke, M. (2012). Exploring the Potential Impact of Reciprocal Peer Tutoring on Higher Education Students' Metacognitive Knowledge and Regulation. Instructional Science, 40(3), 559-588. http://dx.doi.org/10.1007/s11251-011-9190-5

Dimitriadis, G. (2009). Performing identity/performing culture: Hip hop as text, pedagogy, and lived practice. New York, NY: Peter Lang Publishing.

Engel, M. R. (2011). Pop Culture, the Media and Dance: a Boon/Bane Dichotomy. Journal of Dance Education, 14(4), 143-145. http://dx.doi.org/10.1080/15290824.2011.620543

Falchikov, N., \& Goldfinch, J. (2000). Student Peer Assessment in Higher Education: a Meta-Analysis Comparing Peer and Teacher Marks. Review of Educational Research, 70(3), 287-322. http://dx.doi.org/10.3102/00346543070003287

Fogarty, M. (2012). Breaking Expectations: Imagined Affinities in Mediated Youth Cultures. Continuum: Journal of Media \& Cultural Studies, 26(3), 449-462. http://dx.doi.org/10.1080/10304312.2012.665845

Forneris, T., Fries, E., Meyer, A., Buzzard, M., Uguy, S., Ramakrishnan, R., Lewis, C., \& Danish, S. (2010). Results of 
a Rural School-Based Peer-Led Intervention for Youth: Goals for Health. Journal of School Health, 80(2), 57-65. http://dx.doi.org/10.1111/j.1746-1561.2009.00466.x

Frazer-Thomas, J. L., \& Beaudoin, C. (2002). Implementing a Physical Education Curriculum. Two teachers' Experiences. Canadian Journal of Education, 27(2), 249-268. http://dx.doi.org/10.2307/1602223

Galbrait, J., \& Winterbottom, M. (2011). Peer-tutoring: What's in it for the Tutor? Educational Studies, 37(3), 321332. http://dx.doi.org/10.1080/03055698.2010.506330

Graneheim, U. H., \& Lundman, B. (2004). Qualitative Content Analysis in Nursing Research: Concepts, Procedures and Measures to Achieve Trustworthiness. Nurse Education Today, 24(2), 105-112. http://dx.doi.org/10.1016/j.nedt.2003.10.001

Guba, E. G., \& Lincoln, Y. S. (1981). Effective Evaluation: Improving the Usefulness of Evaluation Results through Responsive and Naturalistic Approaches. San Francisco, CA: Jossey-Bass.

Harding, M., \& Haven, B. (2009). The Effects of Peer Coaching in the Secondary Arts Classroom. Intentional Watching in the Dance Studio. Journal of Dance Education, 9(2), 41-51. http://dx.doi.org/10.1080/15290824.2009.10387385

Harris, N., Wilks, L., \& Stewart, D. (2012). HYPEd-up: Youth Dance Culture and Health. Arts \& Health: An International Journal for Research, Policy and Practice, 4(3), 239-248. http://dx.doi.org/10.1080/17533015.2012.677849

Hazzard-Donald, K. (2004). Dance in hip-hop culture. In M. Forman \& M.A. Neal (Eds.). That's the Joint! The Hip-hop Studies Reader. New York: Routledge.

Henning, J. M., Weidner, T. G., Snyder, M., \& Dudley, W. N. (2012). Perceived Frequency of Peer-Assisted Learning In the Laboratory and Collegiate Clinical Settings. Journal of Athletic Training, 47(2), 212-220.

Heron, T. E., Welsch, R. G., \& Goddard, Y. L. (2003). Tutoring Programs Applied in Non-Academic Subject Areas: an Analysis of Skills, Methodology and Results. Remedial and Special Education, 24(5), 288-300. http://dx.doi.org/10.1177/07419325030240050401

Heron, T. E., Villareal, D. M., Yao, M., Christianson, R. J., \& Heron, K. M. (2006). Peer tutoring systems: Applications in classroom and specialized environments. Reading \& Writing Quarterly, 22, 27-45. http://dx.doi.org/10.1080/10573560500203517

Holt, J. E., Kinchin, G., \& Clarke, G. (2012). Effects of Peer-Assessed Feedback, Goal Setting and a Group Contingency on Performance and Learning By 10-12 -Year-Old Academy Soccer Players. Physical Education and Sport Pedagogy, 17(3), 231-250. http://dx.doi.org/10.1080/17408989.2012.690568

Houston-Wilson, C., Lieberman, L., Horton, M., \& Kassler, S. (1997). Peer Tutoring: a Plan for Instructing Students of all Abilities. Journal of Physical Education, Recreation, and Dance, 68(6), 39-44. http://dx.doi.org/10.1080/07303084.1997.10604964

Husu, P., Paronen, O., Suni, J., \& Vasankari, T. (2011). Suomalaisten fyysinen aktiivisuus ja kunto 2010; Terveyttä edistävän liikunnan nykytila ja muutokset. Opetus- ja kulttuuriministeriön julkaisuja. [Physical activity and Fitness of Finns 2010: Current status and changes in health-enhancing physical activity.] Retrieved from: http://www.minedu.fi/export/sites/default/OPM/Julkaisut/2011/liitteet/OKM15.pdf?lang=fi

Irizarry, J. G. (2009). Drawing from Hip-Hop and Urban Youth Culture to Inform Teacher Education. Education and Urban Society, 41, 489-515. http://dx.doi.org/10.1177/0013124508331154

Iserbyt, P., Elen, J., \& Behets, D. (2010). Instructional Guidance in Reciprocal Peer Tutoring With Task Cards. Journal of Teaching in Physical Education, 29(1), 38-53.

Jenkinson, K. A., Naughton, G., \& Benson, A. C. (2014). Peer-assisted Learning in School Physical Education, Sport And Physical Activity Programmes: A Systematic Review. Physical Education and Sport Pedagogy, 19(3), 253-277. http://dx.doi.org/10.1080/17408989.2012.754004

Johnson, M., \& Ward, P. (2001). Effects of Class-Wide Peer Tutoring on Correct Performance of Striking Skills in $3^{\text {rd }}$ Grade Physical Education. Journal of Teaching in Physical Education, 20(3), 247-263.

Keyes, C. L. (2008). The Roots and the Aesthetic Foundation of Hip-Hop Culture. In T. Boyd (Ed.) African Americans and popular culture, Vol. 3.Music and Popular Art. Westport, CT: Greenwood Publishing Group, 87-116.

Lease, A. M., Kennedy, C. A., \& Axelrod, J. L. (2002). Children's Social Constructions of Popularity. Social Development, 11(3), 87-109. http://dx.doi.org/10.1111/1467-9507.00188 
Lengnick-Hall, C. A. (1996). Customer contributions to Quality: A different View of the Customer-oriented Firm. Academy of Management Review, 21(3), 791-824.

Lewis, K. (2014). Pupils' and Teachers' Experiences of School-based Physical Education: a Qualitative Study. BMJ Open, 4. http://doi:10.1136/bmjopen-2014- 005277

Marsh, C. (2012). Hip Hop as Methodology: Ways of Knowing. Canadian Journal of Communication, 37(1), 193-203.

Mayring, P. (2000). Qualitative Content Analysis. Forum: Qualitative social research sozialforschung 1. Retrieved MAY $22^{\text {nd }}, 2013$, from http://www.qualitative-research.net/index.php/fqs/article/view/1089/2386

Miller, D., Topping, K., \& Thurston, A. (2010). Peer Tutoring in Reading: The Effects of Role and Organization on Two Dimensions of Self-esteem. British Journal of Educational Psychology, 80, 417-433. http://dx.doi.org/10.1348/000709909X481652

National Core Curriculum for Upper Secondary Schools. (2003). Ministry of Education. Helsinki. Retrieved May $22^{\text {nd }}$ 2013 fromhttp://www.oph.fi/download/47678_core_curricula_upper_secondary_educati on.pdf

Nurmi, A-M., Hirvensalo, M., \& Klemola, U. (2013). Peer Teaching during a PE Hip Hop Course in Finnish High School-A Pedagogical Challenge for Status and Power. European Journal of Educational Studies, 5(2), 229-244.

Nurmi, A. M., \& Hirvensalo, M. (2007). Hip Hop-kerho Lukion Liikunnanopetuksessa-silta Nuorisokulttuurista Koulukulttuuriin. Liikunta \& Tiede 44(6), 38-42. [Hip hop club in high school physical education-a bridge between youth culture and school culture.]

Ojofeitimi, S., Bronner, S., \& Woo, H. (2012). Injury Incidence in Hip Hop Dance. Scandinavian Journal of Medicine \&Science in Sports, 22(3), 347-355. http://dx.doi.org/10.1111/j.1600-0838.2010.01173.x

Osterman, K. F. (2000). Students' need for belonging in the school community. Review of Educational Research, 70, 323-367. http://dx.doi.org/10.3102/00346543070003323

Pardue, D. (2007). Hip Hop as Pedagogy: A Look into 'Heaven' and 'Soul' in São Paulo, Brazil. Anthropological Quarterly, 80(3), 673-709. http://dx.doi.org/10.1353/anq.2007.0044

Pike, S. (2000). Hip-hop Sport Education. Teaching Elementary Physical Education, 19-21.

Polvi, S., \& Telama R. (2000). The Use of Cooperative Learning as a Social Enhancer in Physical Education. Scandinavian Journal of Educational Research, 44(1), 105-115. http://dx.doi.org/10.1080/713696660

Rohrbeck, C. A., Ginsburg-Block, M. D., Fantuzzo, J. W., \& Miller, T. R. (2003). Peer-assisted Learning Interventions with Elementary School Students: A Meta-Analytic Review. Journal of Educational Psychology, 95(2), 240-257. http://dx.doi.org/10.1037/0022-0663.95.2.240

Romero, A. J. (2012). A pilot test of the Latin active hip hop intervention to increase physical activity among low-income Mexican-American adolescence. American Journal of Health Promotion, 26(4), 208-211. http://dx.doi.org/10.4278/ajhp.090123-ARB-24

Roscoe, R., \& Chi, M. (2007). Understanding Tutor Learning: Knowledge-Building, and Knowledge-Telling in Peer Tutors' Explanations and Questions. Review of Educational Research, 77, 534-574. http://dx.doi.org/10.3102/0034654307309920

Rustad, H. (2012). Dance in Physical Education: Experiences in Dance as Described by Physical Education Student Teachers. Nordic Journal of Dance, 3, 15-29.

Schneider, B., \& Bowen, D. E. (1995). Winning the service game. Boston, NA: Harward Business School Press.

Siedentop, D., \& Tannehill, D. (2000). Developing teaching skills in physical education. Palo Alto, CA: Mayfield.

Stake, E. S. (2000). Qualitative Case Studies. The Sage Handbook of Qualitative Research (2 ${ }^{\text {nd }}$ ed.), 443-466. Thousand Oaks, CA: Sage.

Sungwoon, K., \& Jingu, K. (2007). Mood after Various Brief Exercise and Sport Modes: Aerobics, Hip-hop Dancing, Ice Skating, and Body Conditioning. Perceptual \& Motor Skills, 104(3), 1265-1270. http://dx.doi.org/10.2466/PMS.104.3.1265-1270

Wallhead, T., \& O'Sullivan, M. (2007). A didactic Analysis of Content Development during the Peer Teaching Tasks of a Sport Education Season. Physical Education and Sport Pedagogy, 12(3), 225-243. http://dx.doi.org/10.1080/17408980701610177

Ward, P., \& Lee, M. A. (2005). Peer-assisted Larning in Physical Education: A review of Theory and Research. Journal of Teaching in Physical Education, 24(3), 205-225. 
Weidner, T. G., \& Popp, J. K. (2007). Peer-assistedLearning and Orthopaedic Evaluation Psychomotor Skills. Journal of Athletic Training 42(1), 113-119.

Wood, C. L., Mustian, A. L., \& Lo, Y. (2013). Effects of Supplemental Computer-assisted Reciprocal Peer Tutoring on Kindergarteners' Phoneme Segmentation Fluency. Education and Treatment of Children 36(1), 33-48. http://dx.doi.org/10.1353/etc.2013.0004

\section{$(\mathrm{Cc}) \mathrm{BY}$}

This work is licensed under a Creative Commons Attribution 3.0 License. 